\section{Contents of this Issue}

\section{Articles}

G. Brunner: Direct Chemical Information from Special Radiotracers as well as from Outer X-Ray Excitation (in English) ... 293

M. Richter: Measurement of Ricsidence Timo Distribution with Radiotracers Using Periodic Pseudo-Random Binary Signal Sequences (in English) $\ldots \ldots \ldots \ldots \ldots \ldots . \ldots 29$

St. Szpilowski: Prediction of Mixing Lenth for Transport of Effluent in Rivers (in

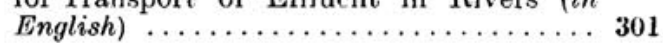

E. Jaworska, I. Kaluska, G. Strselczak: Crosslinking and Free Radical Decay Reactions in Irradiated Polyethylene in Presence of Additives (in English) . . . . . . . . . 305

H. Wagler: Substoichiometric Determination of Pd-II-Traces with Dithizono and Problems of Detormination (in English) .... 307

B. Heinrich, G. Musiol, U.Richter: Fast Analysis of Element Contents by Inclastic Scattering of Neutrons and the Method of Timo Correlated Associated Particles (in

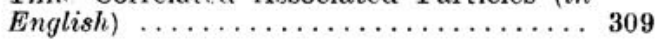

N. S. Batchvarov, I. D. Vankov, L. P. Dimi. trov, Ch. D. Shukov, P. A. Pavlov: Betareflectometer SR-77 (in English) ...... 312

\section{Letters to the Editor}

M. Kießling, B. Schossig: On the Thermal Behaviour of Uranium Hydrides Having Different Isotopic Composition of Hydrogenes $\ldots \ldots \ldots \ldots \ldots \ldots \ldots \ldots \ldots \ldots \ldots \ldots$

Information

New Books

Indexed in Current Contents/PC \& ES Science Citation Index and INIS Atomindex

\section{HANS NEUMANN}

KLAUS SCHÄFER

\section{Elektrische und elektronische Meßtechnik}

(Wissenschaftliche Taschenbücher, Reihe Mathematik/Physik)

1982. 193 Seiten - 98 Abbildungen

4 Tabellen - kl. $8^{\circ}-12,50 \mathrm{M}$

Bestell-Nr. 7630077 (7280)

Die Autoren führen die einen Meßvorgang kenfnzeichnenden Grundbegriffe ein und diskutieren mögliche Meßfehler. Sie beschreiben die Wirkungsweise der wichtigsten elektrischen Meßgeräte, behandeln Meßbrücken und Kompensatoren für die Messung elektrischer Größen, gehen auf den Einsatz von Verstärkerschaltungen in der Meßtechnik ein und erläutern die Wirkungsweise der wichtigsten analogen und digitalen elektronischen Meßsysteme.

Bitte richten Sie Ihre Bestellungen an eine Buchhandlung

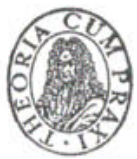

AKADEMIE-VERLAG

DDR-1086 Berlin, Leipziger Str. 3-4 